Relations industrielles

Industrial Relations

\title{
The Young and the Building Trades
}

\section{Marcel Clément}

Volume 4, numéro 6, février 1949

URI : https://id.erudit.org/iderudit/1023497ar

DOI : https://doi.org/10.7202/1023497ar

Aller au sommaire du numéro

Éditeur(s)

Département des relations industrielles de l'Université Laval

ISSN

0034-379X (imprimé)

1703-8138 (numérique)

Découvrir la revue

Citer cet article

Clément, M. (1949). The Young and the Building Trades. Relations industrielles / Industrial Relations, 4(6), 54-56. https://doi.org/10.7202/1023497ar

Tous droits réservés $@$ C Département des relations industrielles de l’Université Laval, 1949
Ce document est protégé par la loi sur le droit d'auteur. L’utilisation des services d'Érudit (y compris la reproduction) est assujettie à sa politique d'utilisation que vous pouvez consulter en ligne.

https://apropos.erudit.org/fr/usagers/politique-dutilisation/ 


\title{
THE YOUNG AND THE BUILDING TRADES
}

\author{
Marcei. Clément
}

\section{A-The Establishment of the Facts}

Since the month of June last, in the course of the inquiry on «man-power in the building industry », we have been lead to study in the light of statistics and in a very special manner the problem of the attitude of the young towards apprenticeship in the building trades. Before attempting any kind of commentary or interpretation, and with the idea of giving to the facts themselves their full scientific value, we will commence by presenting the figures obtained.

TABLE I

Classification by age and by Parity Committee of construction day-labourers as at July 31, 1948 in five Parity Committees

\begin{tabular}{|c|c|c|c|c|c|c|c|c|}
\hline $\begin{array}{c}\text { Parity } \\
\text { Commmittee }\end{array}$ & $\begin{array}{c}\text { less } \\
\text { than } \\
25 \text { yrs }\end{array}$ & $\begin{array}{l}\text { from } \\
25 \text { to } \\
35 \text { yrs }\end{array}$ & $\begin{array}{l}\text { from } \\
35 \text { to } \\
45 \text { yrs }\end{array}$ & $\begin{array}{l}\text { from } \\
45 \text { to } \\
55 \text { yrs }\end{array}$ & $\begin{array}{c}\text { more } \\
\text { than } \\
\mathbf{5 5} \text { yrs }\end{array}$ & Total & $\begin{array}{l}\text { Total }{ }^{1} \text { of } \\
\text { skilled men } \\
\text { \& labourers }\end{array}$ & $\begin{array}{l}\% \text { of labourers } \\
\text { in the total } \\
\text { man-power }\end{array}$ \\
\hline $\begin{array}{l}\text { Montreal } \\
\text { Quebec } \\
\text { Sherbrooke } \\
\text { Three Rivers } \\
\text { Chicoutimi }\end{array}$ & $\begin{array}{r}2,295 \\
1,743 \\
425 \\
397 \\
995\end{array}$ & $\begin{array}{r}1,968 \\
1,493 \\
438 \\
285 \\
640\end{array}$ & $\begin{array}{l}988 \\
865 \\
216 \\
194 \\
320\end{array}$ & $\begin{array}{r}644 \\
407 \\
142 \\
94 \\
163\end{array}$ & $\begin{array}{r}443 \\
180 \\
34 \\
43 \\
129\end{array}$ & $\begin{array}{l}6,348 \\
4.688 \\
1,255 \\
1,033 \\
2,247\end{array}$ & $\begin{array}{r}19,564 \\
11,987 \\
3,531 \\
3,076 \\
4,415\end{array}$ & $\begin{array}{l}32.46 \% \\
33.51 \% \\
35.54 \% \\
32.93 \% \\
50.89 \%\end{array}$ \\
\hline
\end{tabular}

(1) This total applies only to the eight principal trades viz. carpenter, bricklayer, plasterer, plumber, tinsmith, steam-fitter, electrician and painter.

This table clearly shows:

a) that the number of day labourers is higher as the age is lower and that this number decreases rapidly as the age increases;

b) that, except for Chicoutimi (where the Parity Committee's enormous area explains the apprenticeship difficulties) we observe everywhere an average percentage fluctuating between 32 and $35 \%$ of day-labourers in the calling;

c) let us point out that in all the other parity committees, whose membership is much weaker and whose figures we are not publishing, the same two phenomena are to be observed.

Here again is the re-capitulation for the whole Province:

TABLE II

Classification by age of construction day-labourers

in the Province of Quebec

\begin{tabular}{|c|c|c|c|c|c|c|c|c|}
\hline Territory & $\begin{array}{c}\text { less } \\
\text { than } \\
25 \text { yrs }\end{array}$ & $\begin{array}{l}\text { from } \\
25 \text { to } \\
35 \text { yrs }\end{array}$ & $\begin{array}{l}\text { from } \\
35 \text { to } \\
\mathbf{4 5} \text { yrs }\end{array}$ & $\begin{array}{l}\text { from } \\
45 \text { to } \\
55 \text { yrs }\end{array}$ & $\begin{array}{l}\text { more } \\
\text { than } \\
\mathbf{5} 5 \mathrm{yrs}\end{array}$ & Total & $\begin{array}{l}\text { Total of } \\
\text { skilled men } \\
\& \text { labourers }\end{array}$ & $\begin{array}{l}\text { \% of labourers } \\
\text { in the total } \\
\text { man-power }\end{array}$ \\
\hline $\begin{array}{c}\text { Entire } \\
\text { Province }\end{array}$ & 6,164 & 5,077 & 2,772 & 1,535 & 915 & 16,463 & 46,128 & $36 \%$ \\
\hline
\end{tabular}

This table confirms the information furnished above. We note that the overall percentage of 36 for labourers in the total man-power covered by the census would be $33 \%$ if the particular case of Chicoutimi did non interfere with the invaria- bility observable in the other 11 Parity Committees.

On the other hand, calculated on $52 \%$ of its membership, here is the comparison of the average age of skilled men with that of day-labourers in the principal trades. 
TABLE III

Average age of skilled men by trade

\begin{tabular}{l|l}
\hline Plasterers & $42 \mathrm{yrs} 9$ mos. \\
\hline Bricklayers & $41 \mathrm{yrs}$ \\
\hline Carpenters & $40 \mathrm{yrs} 4 \mathrm{mos}$. \\
\hline Painters & $39 \mathrm{yrs}$ \\
\hline Electricians & $36 \mathrm{yrs} 10 \mathrm{mos}$. \\
\hline Plumbers & $36 \mathrm{yrs} 4 \mathrm{mos}$. \\
\hline Tinsmiths & $35 \mathrm{yrs} 3 \mathrm{mos}$. \\
\hline
\end{tabular}

And here is the average age of the daylabourer:

TABLE IV

\begin{tabular}{|l|c|}
\hline \multicolumn{2}{|c|}{ Average age of day-labourer } \\
\hline Day-labourer & 32 yrs 6 mos. \\
\hline
\end{tabular}

It appears clearly at the first reading that all the trades have an average age which fluctuates between 35 and 43 years - only the average age of the day-labourer is less than 33 years. That is to say that the considerable proportion of young day-labourers observed in Tables I and II is not followed by a proportion as high of young journeymen.

\section{B-The Causes}

The study made of the correlations between the preceding phenomena and wages as well as verbal inquiries establishes that in proportions difficult to determine the following phenomena are at the root of the facts observed:

a) the bonus for incompetence resulting from the disparity between the wage of the daylabourer who starts at a rate higher than does the apprentice. Unquestionably, it is legitimate from the moral point of view that the apprentice who acquires knowledge and therefore gives less service and gains a skill as well as money should receive a wage inferior for the time being. But, actually, the young for lack of training prefer an immediate gain and ignore the ultimate benefits from the temporary sacrifice of their apprenticeship; b) the entrepreneur prefers to use the daylabourer rather than to train the apprentice, because the latter costs him more, not in salary but in time. Besides, the apprentice has a tendency to change his employer in order to obtain a higher wage once he begins to understand his trade and the employer then fails to see himself recompenced for the profiency he has permitted his apprentice to acquire;

c) the foremen and the journeymen are generally unfavourable to apprenticeship, particularly in the traditional trades. For that there are two principal causes. On the one hand there is the remembrance of the unemployment following the Crisis of 1928 . It is since this period that the quota in these trades was lowered to $1 / 5$. On the other hand, there is the free competition which causes the oldest who are also the most competent to teach only some easy occupations in order to \&keep themselves in work». They produce a proletarianization of the young with a view to securing themselves against the fear of unemployment. In certain cases one sees the mixture of colours in the painting become a veritable secret which they do not deliver to the apprentices and which is also a mystery to a great many journeymen.

To these three causes of an economic order where the immediate personal interests of the three categories - the young, the entrepreneurs and the journeymen - act against the common interest of the calling and of the Province correspond three causes of a moral order. Actually, the facts stated demonstrate insufficient training:

a) of the young, who generally consider the immediate and not the future gain, who ignore the psychological and social importance of having a trade well in hand and actually seem incapable of the necessary act of will to make a monetary sacrifice at an age when, for the most part, they have not yet assumed the responsibility for a family;

b) of a large number of entrepreneurs who, save where the creation of Apprenticeship Centres such as that of Montreal demonstrate the contrary, do not accept the money sacrifice involved in their moral responsibility to train apprentices however much this may be to their ultimate interest; 
c) of the journeymen who wrongly imagine that the increase in the number of trained «companions» will have a lowering effect on wages. (It is the mechanic trades where the number of apprentices is the highest where the wages are also the highest).

\section{C-The Remedies}

The remedies were clearly indicated in the unanimous resolutions voted at the two last meetings of the Apprenticeship Council at Sherbrooke and Montréal. They can be reduced to two:

a) an educational campaign among potential apprenticeship material, the contractors and the journeymen on the moral level;

b) the development of the policy of the apprenticeship centres and of the pre-apprenticeship schools on the economic level.

The Apprenticeship Assistance Act facilitates the creation of Apprenticeship Commissions certain of which have established schools or preapprenticeship centres. Up until now such centres function regularly at Montreal, Sherbrooke and Chicoutimi, and, as well, night courses for theoretical training are running at Hull, Joliette and Matane. If one takes into account what has been said above on the subject of Three Rivers and Rimouski, the only important city where, although there is an Apprenticeship Committee, nothing effective is being done for the formation of a Centre, is Quebec.

The intensive study which we made in the course of many visits to the different centres allows us to affirm the excellence of the formula being realized as a result of fulfilling the following three conditions:

- the Apprenticeship Centres are undertaken and directed not by the State but by the Profession under the control of the State whence their good adaptation to the ends in view;

-the balance of the theoretical and practical instruction is everywhere realized bearing in mind the secondary differences resulting from local conditions;

-the moral and social training is sufficiently stressed to produce apprentices not only competent in their technique but also conscientious in their work and finally, though not less important, conscious of their social and economic rôle.

The pre-apprenticeship period will not resolve for the apprentice all the problem of apprenticeship but it gives him a training such that a) the entrepreneur will not hesitate to take an apprentice returning a profit superior to that of a day-labourer;

b) the journeyman will have much more trouble hiding his knowledge from an apprentice already trained in the principal operations of his trade;

c) the apprentice himself will be conscious of his technical superiority and will be better able to perfect himself in the course of his apprenticeship with the entrepreneur.

Thus the pre-apprenticeship centre solves partially certain fo the problems stated above. There remains to determine the quantitative importance of their rôle, qualitatively so desirable.

The table below gives the total number of apprentices graduated from the Pre-apprenticeship Centre of Montreal opposite the total of the present apprentices in each trade. The other preapprenticeship centres have not functioned a sufficent time to have their statistics revealing.

\section{TABLE V}

\begin{tabular}{|c|c|c|}
\hline Trades & $\begin{array}{l}\text { Graduated } \\
\text { or studying } \\
\text { at June } \mathbf{3 0} \text {, } \\
\mathbf{1 9 4 8} \mathbf{1}^{1}\end{array}$ & $\begin{array}{c}\text { Total } \\
\text { apprentices } \\
\text { of four } \\
\text { years at } \\
\text { Montreal }\end{array}$ \\
\hline $\begin{array}{l}\text { Carpenters- } \\
\text { joiners } \\
\text { Bricklayers } \\
\text { Plasterers } \\
\text { Tinsmiths } \\
\text { Plumbers } \\
\text { Electricians } \\
\text { Painters }\end{array}$ & $\begin{array}{r}141 \\
204 \\
69 \\
63 \\
87 \\
96 \\
51\end{array}$ & $\begin{array}{r}313 \\
128 \\
129 \\
125 \\
1,312 \\
789 \\
98\end{array}$ \\
\hline Total & 711 & 2.894 \\
\hline
\end{tabular}

Since the opening in Novembre, 1945 These figures are taken from the report of Monsieur A. E. Bourbeau, Director of the Centre, dated June 30, 1948.

As we see, the Pre-apprenticeship Centre of Montreal has really been a life-saver in the area as far as the traditional trades are concerned. Particularly as regards the bricklayers, who, if we take account of the students enrolled at the Centre but not yet apprenticed, owe almost their total apprenticeship to the Centre. However, Montreal's effort is still insufficient with regard to the situation described at the beginning of the second part of this article and this effort must be encouraged by all possible means in the other Parity Committees. 